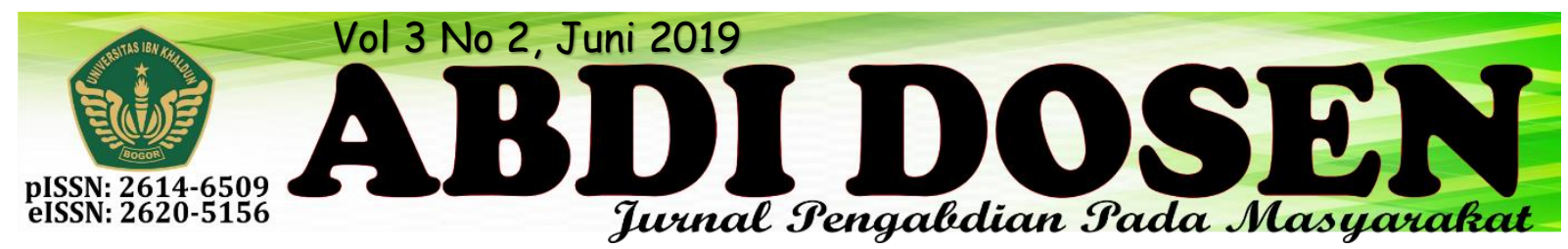

\title{
PENINGKATAN KEMANDIRIAN EKONOMI MASYARAKAT MELALUI PROGRAM DESA WISATA PERTANIAN BERBASIS KECAKAPAN HIDUP DAN PENDIDIKAN KEWIRAUSAHAAN DI DUSUN BABAKAN SAIKHWAN DESA CIBITUNG TENGAH
}

\author{
Syarifah Gustiawati ${ }^{1}$, Fatholloh Fawait, Bayu Sugiri ${ }^{2}$ \\ syarifah@fai.uika-bogor.ac.id \\ Fakultas Agama Islam Universitas Ibn Khaldun ${ }^{1}$, Mahasiswa KKN Kelompok 11 Tahun $2018^{2}$
}

\begin{abstract}
ABSTRAK
Ini merupaka jurnal mengenai laporan Kuliah Kerja Nyata Kelompok 02 KKN UIKA Bogor 2018 di Desa Cibitung Tengah Kecamatan Tenjolaya Kabupaten Bogor, Setelah melalui beberapa survey kami putuskan untuk menetapkan Kampung Babakan Saikhwan sebagi tempat dimana kami akan melaksanakan Kuliah Kerja Nyata, dimana keadaan masyarakat sekitar masih perlu bimbingan untuk mencapai kemandiriana. Penduduk kampung Babakan Saikhwan mayoritas berfropesi sebagai petani, dan tidak sedikit dari anak-anak mereka yang putus sekolah, bergerak dari permasalahan tersebut kami mencoba untuk memberikan solusi melalui beberapa program dan kegiatan yang diharapkan dapat menjadi pemantik bagi mereka untuk menjadi masyarakat yang lebih baik, mandiri dan berdikari.
\end{abstract}

\section{PENDAHULUAN}

Kuliah Kerja Nyata (KKN) merupakan sebuah pembelajaran diluar kampus yang mana mahasiswa berada ditengah-tengah masyarakat dengan harapan mampu membantu dan mendampingi masyarakat untuk dapat memanfaatkan potensi yang ada dan dapat mengatasi permasalahan. Dan tujuan utama dari KKN ini adalah menempatkan mahasiswa di luar kampus agar mahasiswa hidup ditengah-tengah masyarakat bersama masyarakat untuk membantu dan mendampingi masyarakat memanfaatkan potensi sumber daya alam lokal dan sumber daya manusia yang ada untuk mengatasi permasalahan masyarakat dalam kurun waktu tertentu.

KKN Tematik Terintegrasi Berbasis problem solving adalah untuk memecahkan masalah dengan tema tertentu sehingga kegiatan mahasiswa terfokus untuk memecahkan masalah dengan tema tertentu sehingga kegiatan mahasiswa terfokus untuk mengatasi masalah tertentu dan untuk mencapai target tertentu sesuai dengan permasalahannya. Dengan demikian, pada kesempatan ini KKN Tematik Terintegrasi Tahun 2018 Universitas Ibn Khaldun Bogor Kelompok 02 melaksanakan kegiatan KKN dengan tema: "Pemberdayaan Masyarakat Desa Cibitung Tengah dalam Meningkatkan Sumber Daya Manusia Menuju Desa yang Mandiri dan Berdikari”.

Pemberdayaan masyarakat adalah proses pembangunan sumber daya manusia atau masyarakat itu sendiri dalam bentuk penggalian kemampuan pribadi, kreativitas, kompetensi dan daya pikir serta tindakan yang lebih baik dari waktu 
sebelumnya. Pemberdayaan masyarakat sangat penting dan merupakan hal yang wajib untuk dilakukan mengingat pertumbuhan ekonomi dan teknologi yang demikian pesatnya belakangan ini akan sangat mempengaruhi kemampuan tiap individu dalam memenuhi kebutuhan hidupnya.

Desa Mandiri itu mencerminkan kemauan masyarakat desa yang kuat untuk maju, dihasilkannya produk atau karya desa yang membanggakan dan kemampuan desa untuk memenuhi kebutuhankebutuhannya. Desa mandiri bertumpu pada trisakti desa yaitu: karsa, karya, sembada. Jika trisaksi desa dapat dicapai maka desa itu disebut sebagai desa yang berdikari. Karsa, karya, sembada desa mencakup bidang ekonomi, budaya dan

\section{METODOLOGI}

Lokasi KKN ini terletak di desa Cibitung Tengah Kecamatan Tenjolaya Kabupaten Bogor. Penentuan informan menggunakan teknik penelitian tindakan yaitu penelitian yang bertujuan untuk mengembangkan keterampilan keterampilan baru, cara pendekatan baru atau suatu produk pengetahuan baru untuk memecahkan masalah dengan penerapan langsung di lapangan secara nyata.[1]

Adapun metode pendekatan yang digunakan dalam kegiatan ini adalah: (1) Pendekatan religius; (2) Pendekatan organisasi; (3) Pendekatan kekerabatan; (4)

\section{HASIL DAN PEMBAHASAN}

Desa Cibitung Tengah merupakan salah satu desa yang memiliki potensi dalam peningkatan sumber daya manusia dan ekonomi masyarakat melalui pemanfaatan sumber daya alamnya. Pemandangan alam yang membentang, social yang bertumpu pada tiga daya yakni perkembangan kegiatan ekonomi desa dan antar desa, semakin kuatnya system partisipatif desa, serta terbangunnya masyarakat di desa yang kuat secara ekonomi dan social budaya serta mempunyai kepedulian tinggi terhadap pembangunan serta pemberdayaan desa.

Salah satu desa yang memiliki potensi dalam peningkatan sumber daya manusia dan ekonomi masyarakat melalui pemanfaatan sumber daya alam adalah Desa Cibitung Tengah Kecamatan Tenjolaya Kabupaten Bogor. Karena letak desa ini sangatlah strategis dan memiliki sumber daya alam yang melimpah serta adanya pusat perdagangan yang menjadikan desa ini memiliki potensi dalam meningkatkan ekonomi masyarakat.

Pendekatan berdasarkan karakter masyarakat.

Teknik pengumpulan data dalam program ini dilakukan dengan observasi, wawancara dan dokumentasi. Data yang terkumpul dianalisis secara deskriptif kualitatif. Dimana suatu upaya yang dilakukan bekerja dengan data, mengorganisasikan data, memilahmilahnya menjadi satuan yang dapat dikelola, menemukan apa yang penting dari apa yang dipelajari dan memutuskan apa yang dapat lakukan.

berbagai macam jenis perkebunan, pesawahan yang luas dan suasana yang sejuk dan damai menjadi kelebihan desa tersebut. Namun, terlepas dari semua kelebihan itu, kesadaran masyarakat akan 
besarnya potensi yang ada di desa masih sangat kurang.

Desa Cibitung Tengah juga merupakan pusat dari Pendidikan di Kecamatan Tenjolaya, namun tidak sedikit pula remaja-remaja yang putus sekolah yang disebabkan oleh permasalahan ekonomi dari keluarga. Selain itu masih sedikitnya minat wirausaha pada remaja sehingga mata pencaharian yang ada hanya terfokus pada pertanian. Kurangnya pengadaan infrastruktur yang ada, menjadi faktor sedikit terhambatnya kegiatan distribusi hasil produksi pertanian.

Berkaca dari permasalahanpermasalahan yang telah dipaparkan diatas, solusi yang kami tawarkan adalah dengan membuat program-program selama 30 hari yang terfokus di bidang: Keagamaan; Ekonomi; Kesehatan serta Pendidikan. Adapun program-program yang kami buat adalah hasil pengamatan selama di lokasi. Program-program ini dibuat berdasarkan kebutuhan masyarakat setempat dengan diadakannya sosialisasi oleh Pengurus Desa, RW, RT, dan Tokoh Masyarakat.

\section{Pelaksanaan Program Kegiatan}

\section{Keagamaan}

Keagamaan merupakan sarana yang sangat penting dan dibutuhkan untuk menumbuhkan karakter keislaman pada masyarakat yang ada di Desa Cibitung Tengah. Selain itu, agama sangatlah penting dalam kehidupan manusia. Demikian pentingnya agama dalam kehidupan manusia, sehingga diakui atau tidak sesungguhnya manusia sangatlah membutuhkan agama. Dan sangatlah dibutuhkannya agama oleh manusia, tidak saja di masa primitive dulu sewaktu ilmu pengetahuan belum berkembang, tetapi juga di zaman modern sekarang sewaktu ilmu dan teknologi sedemikian maju agama harus tetap ada. Meskipun demikian, pendidikan agama nampaknya masih sangat rendah di kalangan masyarakat. Masjid dan mushalla tidak banyak ditemukan. Kehidupan masyarakat pedesaan yang kurang tersentuh oleh siraman rohani menjadikan mereka mengalami kegersangan spiritual.

\section{a. Pengajian Rutin}

Kegiatan ini dilakukan secara rutin setiap hari Kamis malam Jumat ba'da maghrib di Masjid AlUrwahtul Wustqo. Kegiatan ini selain meningkatkan keagamaan masyarakat juga menjadi alat silaturahmi masyarakat yang ada di kampung babakan saikhwan karena di pengajian rutin ini hampir seluruh masyarakat yang ada ikut serta dalam kegiatan tersebut.

b. Mengajar ngaji

Kegiatan mengajar ngaji di Kampung Babakan Saikhwan dilaksanakan sebanyak 6 kali dalam seminggu terkecuali pada hari kamis. Waktu pelaksanaan mengajar ngaji ini dimulai ba'da maghrib sampai isya bertempat di Masjid Al-Urwahtul Wustqo. Pada pengajaran ngaji ini mahasiswa membantu tokoh masyarakat memberikan pengetahuan keagamaan sejak usia dini. Selain itu pelaksanaan mengajar ngaji ini juga bertujuan untuk memotivasi anak-anak untuk rajin mengaji agar mendapatkan bekal dunia dan akhirat.

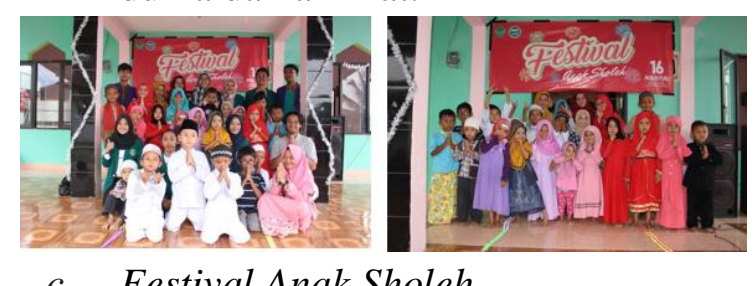

c. Festival Anak Sholeh

Festival Anak Sholeh adalah program yang diadakan dengan 
tujuan untuk meningkatkan semangat anak-anak mengenal ilmu agama dan juga dapat mengukur sejauh mana ilmu mereka peroleh karena anak sholeh dan sholehah merupakan aset keluarga dan anugrah. Sepantasnya mereka mendapatkan dorongan dan penghargaan untuk komentarkomentar terpuji mereka. Melalui festival anak sholeh dan sholehah, mempersiapkan generasi penerus yang beriman, bertaqwa dan berakhlak mulia.

\section{d. Takbir Bersama}

Kegiatan ini diadakan pada tanggal 21 Agustus 2018 bertepatan dengan malam Takbir Idul Adha $1439 \mathrm{H}$. Kegiatan ini dilakukan mahasiswa bersama dengan para pemuda dan anak-anak yang ada di Kampung Babakan Saikhwan untuk menyemaraki malam takbir idul adha.

\section{Ekonomi}

\section{a. Program Desa Wisata}

Program Desa Wisata adalah salah satu program unggulan kami yang dimana bertujuan untuk meningkatkan ekonomi masyarakat dengan pemanfaatan sumber daya alam dan sumber daya manusia yang ada di desa Cibitung Tengah. Dalam hal ini, kami merngonsepkan beberapa hal untuk membanngun desa wisata ini, yaitu: langkah pertama yang dilakukan adalah penanaman 1000 pohon di kampung babakan saikhwan. Selanjutnya, merevitalisasi penerangan jalanan umum sekitar kampung babakan saihkwan. Serta peremajaan fasilitasfasilitas yang ada di kampung babakan saikhwan seperti gapura dan saung desa. Program ini bekerja sama dengan BPDAS IPB dan Korem Bogor. Pelaksanaan program ini diikuti juga oleh masyarakat kampung babakan saikhwan.

- Penanaman 1000 Pohon

Maksud dan tujuan dilaksanakannya penanaman pohon ini adalah untuk meningkatkan kepedulian dari berbagai pihak, akan pentingnya penanaman dan pemeliharaan pohon yang berkelanjutan dalam mengurangi dampak pemanasan global dan mencegah kekeringan serta tanah longsor. Program ini dilaksanakan tanggal 02 September 2018. Kegiatan ini diikut sertakan oleh para tokoh dan masyarakat setempat, dan dihadiri pihak akademi militer yang melibatkan Koramil, Babinsa dan Dosen Pembimbing Lapangan.

- Peremajaan Gapura Selamat Datang Gapura adalah suatu struktur yang merupakan pintu atau gerbang ke suatu kawasan yang didesain sedemikian rupa untuk menarik perhatian para pengunjung. Melihat gapura yang menyambut kawasan kampung Babakan Saikhwan sudah memerlukan pembaharuan, maka kami bergerak untuk sedikit meremajakan (membantu perbaikan) pada gapura tersebut dengan maksud dan tujuan memperindah sekaligus mempercantik program Desa Wisata. Diantaranya memberikan ucapan selamat datang dan memberikan warna berupa lapisan/vernis untuk pengawetan kayu serta pagar bambu.

Catatan. Program Desa Wisata merupakan Program Unggulan. Jurnal mengenai pembahasan lebih lengkap mengenai program ini terpisah. 


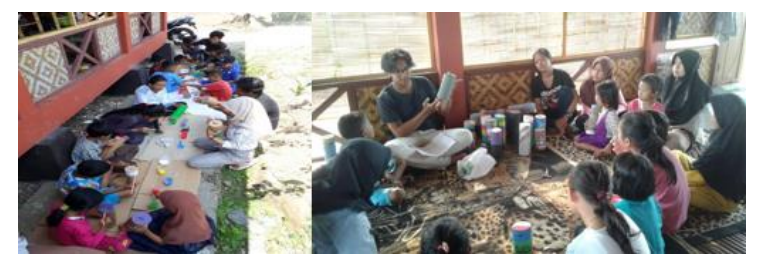

b. Gerakan Menabung Sejak Dini

Menabung merupakan salah satu langkah sederhana supaya kita dapat menyisihkan sebagian dana dari penghasilan untuk disimpan. Bahkan tak jarang sebagian orang menabung sejak usia dini. Berapapun nilainya, nyatanya kegiatan menabung ini sangat bermanfaat, sebab menabung bisa digunakan agar kita terhindar dari utang. Selain itu, jika kita memiliki tabungan tentunya tidak perlu mengkhawatirkan hal-hal yang tidak perlu, mengingat kita sudah memiliki dana cadangan

\section{Kesehatan}

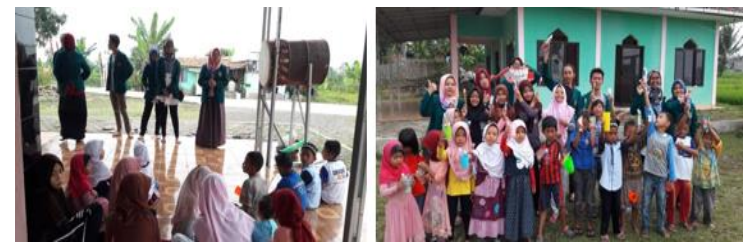

a. Penyuluhan PHBS

Pelatihan perilaku hidup bersih dan sehat merupakan salah satu cara sederhana dalam upaya peningkatan kesehatan masyarakat yang ada di desa cibitung tengah ini. Walaupun pelatihan perilaku hidup bersih dan sehat yang dilakukan secara sederhana dan sasarannya kepada anak-anak namun dengan hal-hal kecil seperti ini setidaknya dapat menimbulkan kesadaran pada anakanak tentang hal-hal kecil yang dapat berpengaruh terhadap kesehatan mereka.

\section{b. Kerja Bakti}

Kegiatan ini dilakukan dengan tujuan untuk menjadikan kampung babakan saikhwan menjadi kampung yang bersih dan sehat. Kegiatan ini dilakukan secara rutin satu minggu sekali. Mahasiswa dibantu masyarakat untuk merealisasikan tujuan dari kegiatan ini.

c. Penanaman Apotek Hidup

Program ini dilakukan dengan cara memanfaatkan lahan yang ada untuk ditanamani tanaman-tanaman herbal. Tanaman-tanaman herbal yang tersedia dapat langsung dimanfaatkan masyarakat untuk menjadi obat. Persiapan program ini dimulai pada tanggal 23 Agustus s/d 31 Agustus 2018 dengan melibatkan masyarakat yang ada di kampung babakan saikhwan untuk merealisasikan program penanaman apotek hidup tersebut.

\section{d. Lari Pagi}

Kegiatan ini dilakukan mahasiswa bersama anak-anak kampung babakan saikhwan setiap hari minggu pagi. Adanya kegiatan ini bertujuan untuk meningkatkan kesehatan anakanak serta salah satu upaya pendekatan mahasiswa kepada masyarakat.

\section{Pendidikan}

Pendidikan merupakan sarana yang sangat penting dan dibutuhkan untuk mengembangkan kompetensi dan kemampuan masyarakat serta mengembangkan pola pikir menjadi lebih baik. Dalam mengenyam dunia pendidikan tentunya dibutuhkan fasilitas-fasilitas yang memadai demi tercapainya tujuan dari pendidikan itu sendiri, seperti misalnya keuangan, sumber daya pengajar dan fasilitas belajar. Meskipun demikian, tidak semua masyarakat mampu mengenyam dunia pendidikan dengan fasilitas yang memadai, seperti halnya di Kampung Babakan Saikhwan mereka masih memiliki 
hambatan-hambatan dalam mendapatkan pendidikan yang layak seperti minimnya fasilitas belajar.

\section{a. Belajar Bersama}

Sasaran kegiatan ini adalah anakanak SD dan SMP. Dilaksanakan pukul $\quad 15.30 \quad$ s/d $\quad 17.00 \quad$ WIB bertempat di saung desa sehat yang berlokasi tidak jauh dari posko. Kegiatan ini diantaranya adalah membantu anak-anak belajar baca, tulis dan hitung (calistung), membantu anak-anak mengerjakan PR dari sekolahnya, dan memotivasi mereka agar semangat belajar.

b. Pengenalan Teknologi Informasi

Perkembangan teknologi yang meningkat, memaksa setiap pelajar untuk menguasai teknologi informasi. Dengan tidak adanya pengajaran mengenai teknologi informasi di sekolah, khususnya di Kampung Babakan Saikhwan. Melalui program ini, kami mencoba mengenalkan teknik dasar penguasaan teknologi informasi, diantaranya pengoperasian dasar laptop dan penggunaan Microsoft Word. Kegiatan ini dilakukan di posko hari Sabtu pukul 16.00 s/d 17.00 WIB.

c. Kelas Bahasa Inggris

Sasaran kegiatan ini ditujukan kepada anak-anak kelas III SD hingga SMP. Dilaksanakan setiap hari senin s/d jumat pukul $15.30 \mathrm{~s} / \mathrm{d}$ 17.30 WIB. Materi yang diajarkan adalah mengajarkan bahasa inggris nama-nama benda disekeliling mereka, nama, dan cara memperkenalkan diri dalam bahasa inggris.

\section{d. Revitalisasi Taman Baca}

Fungsi taman baca sebagai tempat belajar dan mencari informasi yang dibutuhkan masyarakat baik mengenai masalah yang langsung berhubungan dengan masalah pendidikan maupun bukan pendidikan. Program ini adalah upaya kami untuk revitalisasi taman baca yang sudah ada sebelumnya. Diantaranya memperbaiki rak buku, menambahkan dan mengelompokkan buku sesuai kategori. Taman baca ini berlokasi di Masjid Al-Urwahtul Wustqo.

\section{Hukum}

e. Sosialisasi Sadar Lalu Lintas

Pemahaman masyarakat khususnya pelajar mengenai keselamatan berlalu lintas terutama dalam mematuhi rambu-rambu lalu lintas dirasa masih sangat kurang. Melalui program ini kami mencoba memberikan sedikit pemahaman terhadap keselamatan dan patuh lalu lintas. Dan yang menjadi sasaran program ini adalah siswa-siswi SMK Putera Pelita dengan harapan dapat memberikan perubahan terhadap sikap berlalu lintas. Program ini dilaksanakan pada tanggal 30 Agustus 2018 Pukul 09.00 s/d 12.00 WIB.

\section{Teknik}

\section{f. Penerangan Jalan Umum}

Penerangan jalan umum adalah lampu yang digunakan untuk penerangan jalan di malam hari sehingga mempermudah pejalan kaki. Meningkatkan keselamatan lalu lintas dan keamanan dari para pengguna jalan. Namun di kampung Babakan Saikhwan penerangan jalan umum sangatlah minim (tidak 
berfungsi). Maka dari itu, melalui program ini kami berupaya untuk merevitalisasi penerangan jalan umum dengan mengganti kabel dengan kabel yang berstandar dan

\section{KESIMPULAN}

Kegiatan Kuliah Kerja Nyata (KKN) Tematik Terintegrasi Tahun 2018 Universitas Ibn Khaldun merupakan salah satu kegiatan dengan pendekatan community development, dimana pada pelaksanaan kegiatan ini melakukan proses perencanaan sekaligus aksi program Pemdampingan masyarakat baik pada aspek sosial, ekonomi, kesehatan, pendidikan, hukum dan agama maupun teknologi tepat guna secara terpadu.

Selama 30 hari menjalani program kegiatan di Desa Cibitung Tengah, Tenjolaya-Bogor, semua program kegiatan kami mendapat respon positif dari warga setempat. Selain itu, keterlibatan dan partisipasi masyarakat dalam program kerja kami sungguh membantu dan memudahkan kami menyelesaikan semua program yang telah terencana dan tersusun rapih.

Dan berdasarkan hasil pengamatan kami selama satu bulan dengan melaksanakan berbagai program kegiatan yang telah terpaparkan diatas, kami berharap ke depan masyarakat desa bisa lebih mandiri lagi dan terus memberikan inovasi untuk kemajuan desa, terlebih mengganti lampu dengan yang standar pula. Program ini dilaksanakan tanggal 01 September 2018.

khususnya Kampung Babakan Saikhwan. Kami pun berharap masyarakat setempat terus bekerjasama mengembangkan serta memanfaatkan segala potensi yang ada sehingga terwujud masyarakat desa yang mandiri dan berdikari.

Berikut beberapa kesimpulan yang dapat kami jabarkan selama program KKN yang berlangsung kurang lebih selama 30 hari di Desa Cibitung Tengah Kecamatan Tenjolaya :

1. Terealisasinya program pengabdian kepada masyarakat yang dilakukan oleh mahasiswa dalam rangka mewujudkan program Universitas Ibn Khaldun Bogor sesuai dengan Visi dan Misi Universitas Ibn Khaldun Bogor.

2. Terbentuknya karakter building para mahasiswa dan mahasiswi yang mengikuti program $\mathrm{KKN}$ ini.

3. Terbentuknya program kerjasama langsung antara mahasiswa dan masyarakat yang bisa saling bersinergi dan saling menguntungkan.

4. Meningkatkan kepedulian dan rasa empati mahasiswa kepada permasalahan masyarakat, sehingga terjadinya perubahan perilaku mahasiswa. 


\section{REFERENSI}

2018, Pedoman Pelaporan LPPM Uiversitas Ibn Khaldun Bogor, Bogor : LPPM UIKA

https://www.google.com/amp/s/kerjamemb angundesa.wordpress.com/2015/11/2 3/konsep-desa-mandiri

http://www.pengertianmenurutparaahli.net/ pengertian-pemberdayaan masyarakat-dan-contohnya/ 